\title{
Ketepatan Komunikasi antara Manajemen dan Awak Kabin (Flight Attendant) di PT. Garuda Indonesia
}

\author{
Surti Wardani \\ Fakultas Ekonomi Universitas Pamulang \\ Email: dosen1707@unpam.ac.id \\ Article Submitted 15 Juli 2018, Revised 16 Agustus 2018, Accepted 29 Agustus 2018
}

\begin{abstract}
ABSTRAK
Penelitian ini bertujuan untuk mengetahui ketepatan komunikasi berdasarkan enam elemen komunikasi dalam proses komunikasi antara manajemen dengan Awak Kabin di PT. Garuda Indonesia. Penelitian ini adalah penelitian kualitatif dan menggunakan pendekatan fenomenologi dengan model paradigma naturalistik (naturalistic inquiry). Data penelitian diperoleh melalui observasi partisipatif, wawancara mendalam dan studi dokumentasi, sementara teknik analisis data yang digunakan adalah analisis induktif. Hasil penelitian ini menunjukkan bahwa manajemen menerapkan sistem keterbukaan dalam berkomunikasi dengan awak kabin, termasuk mengutamakan komunikasi secara tatap muka dan juga mempraktikkan human relation sebagai landasan berkomunikasi. Penyusunan pesan juga dilakukan dengan penyesuaian; apabila bersifat persuasif, akan digunakan kalimat persuasif, begitu pula apabila pesan bersifat informasi (narasi) atau argumentasi. Sedangkan pemilihan channel dilakukan dengan memperhatikan jika penerima (receiver) bisa menyandi balik (decode) agar bisa memunculkan feedback positif, termasuk juga dengan memanfaatkan media sosial seperti Facebook, Twitter, Instagram, dan Whatsapp. Sementara hambatan yang ditemui dalam proses komunikasi yang berlangsung ialah tingginya mobilitas awak kabin dan keengganan awak kabin untuk berkomunikasi dengan pihak manajemen (komunikasi ke atas) meskipun keterbukaan komunikasi telah dilakukan.
\end{abstract}

Kata Kunci: Komunikasi organisasi, ketepatan komunikasi, Garuda Indonesia

\begin{abstract}
This research aims to determine the fidelity of communication based on the six (6) communication elements in the communication process between management and cabin crew at PT. Garuda Indonesia. This study is qualitative research, using phenomenology approach with naturalistic inquiry model. The research data was obtained through participative observation, in-depth interview and documentation study, while the data analysis technique uses inductive analysis. The results of this study shows that management has implement an openness system in communicating with cabin crew, including prioritizing face-to-face communication and also practicing human relations as the foundation to communicate. Preparation of messages is done with adjustment; persuasive sentences are used if the messages is persuasive, as well as if the message is information (narrative) or argumentation. The channel selection is choosed with attention so receiver (receiver) can encode back (decode) in order to generate positive feedback, including utilizing social media like Facebook, Twitter, Instagram, and Whatsapp. The obstacles encountered in the communication process was the high mobility of cabin crew and the reluctance of the cabin crew to communicate with management, even the openness communication system has been implemented.
\end{abstract}

Keywords: Organizational communication, fidelity of communication, Garuda Indonesia

Citation : Wardani, Surti. (2018). “Ketepatan Komunikasi antara Manajemen dan Awak Kabin (Flight Attendant) di PT. Garuda Indonesia". Nyimak Journal of Communication, 2(2): 151-165. 


\section{PENDAHULUAN}

Setiap proses komunikasi mempunyai nilai ketepatan (fidelity). Dalam komunikasi organisasi yang melibatkan atasan dan bawahan, ketepatan komunikasi juga merupakan hal penting, karena terkait dengan berhasil atau tidaknya program perusahaan yang sudah direncanakan dan dijalankan untuk mencapai tujuan perusahaan. Dalam hal ini, ketepatan menjadi tanggung jawab masing-masing pihak baik itu dari manajemen maupun pegawai, yang berperan sebagai pengirim-penyandi (source-encoder) dan penerima-penyandi balik (receiver-decoder). Posisi atau peran source-encoder dan receiver-decoder, dapat dimiliki oleh setiap unit/departemen dan individu/pegawai, terlepas posisi/jabatan orang/pegawai tersebut dalam perusahaan (Ingsih, 2011; Kuswarno, 2001; Prabawanti, 2008). Sebagai contoh adalah proses komunikasi antara pegawai dan manajemen pada unit Cabin Services yang merupakan bagian dari komunikasi organisasi dalam PT Garuda Indonesia.

Dalam unit Cabin Services, terdapat salah satu front liner yang berhadapan secara langsung dengan pelanggan: Awak Kabin. Awak kabin sendiri mempunyai waktu terlama dalam menghadapi pelanggan, karena mereka terbang bersama pelanggan dalam setiap tugas yang dijadwalkan perusahaan. Dalam hubungannya dengan pihak manajemen perusahaan, Awak Kabin berada di bawah pembinaan Chief Flight Attendant. Dalam bahasa lain, pengelolaan Awak Kabin terpusat di unit ini (Cabin Services).

Sementara itu, sifat unik serta khas yang dimiliki Awak Kabin menimbulkan suatu persoalan tersendiri, yaitu menyebabkan mudah terbentuknya celah dalam berkomunikasi, terutama antara Chief atau pihak manajemen dengan Awak Kabin. Hal ini misalnya dapat dilihat dari munculnya berbagai istilah, seperti "Chief favorit", "Chief galak", atau "Chief khusus untuk jual beli jadwal terbang", dan lain-lain. Semuanya kemudian menimbulkan keengganan Awak Kabin untuk datang atau berhubungan (berkomunikasi) dengan "pihak manajemen".

Fenomena lainnya yang tampak ialah awak kabin sering mengeluhkan kurangnya informasi dari pihak manajemen. Padahal informasi menjadi salah satu hal penting karena mereka bertugas dan berhadapan langsung dengan pelanggan. Salah satu upaya yang telah dilakukan adalah melakukan proses komunikasi tatap muka untuk menutup celah atau gap yang timbul (Afriyadi, 2015; Londa, Senduk \& Boham, 2014; Nurhayani, 2011; Suherman, 2010; Wijaya; 2013). Karena sejatinya, apabila proses komunikasi dari pihak manajemen terhadap unitunit yang ada di bawahnya mengalami kendala, tidak menutup kemungkinan apabila proses transformasi ke arah yang lebih baik yang hendak diwujudkan dapat terhambat dan terganggu (Harivarman; 2017; Klimova \& Semradova, 2012; Lunenburg, 2010; Pricilia, 2013; Sidauruk, 2013). 
Adapun beberapa masalah yang diidentifikasi dalam penelitian ini adalah: (1) proses komunikasi vertikal dan horisontal yang belum berjalan efektif; (2) terdapat celah komunikasi antara manajemen dan pegawai operasional (awak kabin); (3) masih kurangnya kuantitas serta kualitas komunikasi antara pihak manajemen dengan pegawai (awak kabin); dan (4) ketepatan komunikasi dalam proses komunikasi di antara pihak manajemen dan awak kabin perlu diperhatikan untuk menunjang proses transformasi perusahaan, dan agar komunikasi menjadi efektif.

Berdasarkan identifikasi masalah di atas, penelitian ini bertujuan untuk mengetahui proses komunikasi atau interaksi yang terjadi antara manajemen dengan awak kabin PT. Garuda Indonesia dan mengetahui ketepatan komunikasi berdasarkan enam elemen dasar komunikasi dalam proses komunikasi: sender, decoder, message, channel, receiver dan encoder.

\section{KERANGKA TEORI}

\section{Komunikasi dalam Organisasi}

Proses komunikasi dalam sebuah organisasi (komunikasi) melibatkan keseluruhan individu yang berada dalam organisasi tersebut yang disesuaikan dengan fungsi dan peran masingmasing. Pemimpin, sebagai pengambil keputusan dan kebijakan (decision maker), harus mampu meneruskan dan mengalirkan informasi yang berada di atas supaya sampai pada tingkat operasional. Penggunaan media yang tepat akan sangat membantu, terutama dengan tingkat akses yang tinggi.

Menurut Brent D. Ruben (1993) esensi komunikasi merupakan fungsi sehari-hari dalam organisasi. Lewat komunikasi para anggota organisasi akan melakukan hal-hal seperti menentukan tujuan (define goal), menetapkan fungsi dan tanggung jawab masing-masing (delineates roles and responsibilities of members), melakukan kontrol operasional (control operation), membangun jaringan informasi (establish information network) serta membangun budaya dan iklim (develop the culture and climate).

Stewart L. Tubbs dan Sylvia Moss (1996) menyatakan bahwa pengembangan dan pemeliharaan sistem komunikasi menjadi fungsi utama yang diemban eksekutif. Jadi, komunikasi yang dilakukan oleh pihak manajemen akan memengaruhi tingkatan yang ada di bawahnya. Selain itu, kemampuan berkomunikasi seorang pemimpin pada sebuah unit juga akan memberikan arti pada unit dan diri pemimpin itu sendiri. 


\section{Komunikasi Organisasi}

Gerald M. Goldhaber (dalam Sendjaja, 1999) menyatakan bahwa komunikasi organisasi diberi batasan sebagai arus pesan dalam suatu jaringan yang sifat hubungannya saling tergantung satu sama lain. Sementara R. Wayne Face dan Don F. Faules (2000) mendefinisikan komunikasi organisasi sebagai pertunjukan dan penafsiran pesan di antara unit-unit komunikasi yang merupakan bagian dari organisasi. Organisasi terdiri dari unit-unit komunikasi dalam hubungan-hubungan hierarkis antaranggota serta berfungsi dalam suatu lingkungan.

Dalam organisasi, komunikasi punya empat fungsi sebagaimana berikut (Sendjaja, 1999).

1. Fungsi Informatif

Organisasi dilihat sebagai suatu sistem pemrosesan informasi (information-processing system) di mana seluruh anggota organisasi berharap bisa memperoleh informasi yang lebih banyak, lebih baik dan tepat waktu. Dengan informasi yang didapatkan, anggota organisasi dapat melaksanakan pekerjaannya secara lebih pasti.

2. Fungsi Regulatif

Fungsi regulatif berkaitan dengan peraturan-peraturan yang ada pada suatu organisasi. Pada semua organisasi terdapat dua hal yang berpengaruh kepada fungsi ini. Pertama, atasan (manajemen) yang punya kewenangan untuk mengendalikan seluruh informasi yang disampaikan. Kedua, terkait dengan pesan (message). Artinya, pesan-pesan yang bersifat regulatif pada dasarnya berorientasi pada kerja di mana bawahan memerlukan kepastian peraturan tentang pekerjaan yang boleh dan tidak boleh untuk dilaksanakan.

3. Fungsi Persuasif

Dalam mengatur organisasi, kekuasaan dan kewenangan tidak akan selalu membawa hasil sesuai dengan yang diharapkan. Oleh karena itu, banyak pimpinan lebih memilih mempersuasi bawahannya daripada memberi perintah, karena sebuah pekerjaan yang dilakukan secara sukarela akan menghasilkan kepedulian yang lebih besar dibanding ketika pimpinan memperlihatkan kekuasaan dan kewenangannya terhadap karyawan.

4. Fungsi Integratif

Setiap organisasi berusaha menyediakan saluran yang memungkinkan karyawan dapat menjalani tugas dan pekerjaan dengan baik. Ada dua saluran komunikasi yang dapat mewujudkan hal tersebut, yaitu saluran komunikasi formal, seperti penerbitan khusus dalam organisasi tersebut (newsletter, bulettin) dan laporan kemajuan organisasi; juga saluran komunikasi informal, seperti perbincangan antarpribadi selama masa istirahat kerja, pertandingan olahraga atau kegiatan darmawisata. 


\section{Komunikasi ke Atas dan ke Bawah dalam Organisasi}

Salah satu tantangan terbesar dalam komunikasi organisasi adalah menyampaikan informasi ke seluruh bagian di dalam organisasi serta bagaimana menerima informasi dari semua bagian organisasi. Proses ini berhubungan dengan aliran informasi dan merupakan proses yang rumit (Pace \& Faules, 2000).

Davis (dalam Pace \& Faules, 2000) menerangkan arti komunikasi ke bawah dalam organisasi sebagai arus informasi yang mengalir dari jabatan yang berotoritas lebih tinggi kepada mereka yang berotoritas lebih rendah. Dengan demikian pegawai di seluruh tingkat dalam organisasi harus memiliki akses terhadap informasi, baik informasi tentang bagaimana melakukan pekerjaan, mengenai dasar pemikiran untuk melakukan pekerjaan, mengenai kebijakan serta berbagai praktik organisasi, mengenai kinerja pegawai, maupun informasi guna mengembangkan rasa memiliki terhadap tugas tertentu (sense of mission), termasuk juga pemberian motivasi kepada seluruh pegawai supaya bisa bekerja lebih baik lagi.

Menurut Level dan Galle (dalam Pace \& Faules, 2000) terdapat enam kriteria yang sering digunakan sebagai metode atau cara penyampaian informasi kepada pegawai.

1. Ketersedian

Metode-metode yang tersedia dalam organisasi dan cenderung dipergunakan. Setelah menginventarisasikan metode yang tersedia organisasi dapat memutuskan metode apa yang dapat ditambahkan bagi suatu program keseluruhan yang lebih efektif.

2. Biaya

Metode yang dinilai paling murah cenderung dipilih untuk penyebaran informasi yang tidak rutin dan mendesak; metode yang lebih mahal tetapi lebih cepat.

3. Pengaruh

Metode yang tampaknya memberikan pengaruh atau kesan paling besar sering dipilih daripada metode yang baku.

4. Relevansi

Metode yang tampak paling relevan dengan tujuan yang ingin diraih akan lebih sering dipilih. Bila tujuannya singkat dan sekadar menyampaikan informasi, dapat dilakukan dengan pembicaran diikuti oleh memo. Tetapi, jika tujuannya menyampaikan masalah yang rinciannya rumit, metode laporan teknis tertulis menjadi metode yang mungkin akan dipilih. 


\section{Respon}

Metode yang dipakai akan dipengaruhi ketentuan apakah dikehendaki atau diperlukan respons khusus terhadap informasi tersebut. Di dalam lingkungan pelatihan, mungkin diinginkan menggunakan metode yang memungkinkan serta dapat mendorong peserta pelatihan untuk bersikap tanggap dan mengajukan pertanyaan, pertemuan tatap muka mungkin menjadi metode yang dipilih.

6. Keahlian

Metode yang tampaknya sesuai dengan kemampuan pengirim untuk menggunakannya dan dengan kemampuan penerima guna memahaminya cenderung digunakan daripada metode yang tampaknya di luar kemampuan pemahaman pegawai yang menerimanya. Brosur-brosur yang berkilat-kilat sebaiknya tidak digunakan bila komunikator merasa tidak mampu membuatnya; bila tingkat pendidikan pegawai terbatas, instruksi manual yang rumit mungkin bukan metode yang baik untuk digunakan.

Sementara itu, komunikasi ke atas dalam organisasi menunjukkan aliran informasi yang mengalir dari tingkat yang lebih rendah (bawahan) ke tingkat lebih tinggi (penyelia), di mana pegawai atau bawahan dapat memiliki alasan yang baik atau meminta informasi dari atau memberi informasi kepada seseorang yang otoritasnya lebih tinggi dari dirinya. Sebuah permohonan atau komentar yang diarahkan terhadap individu yang otoritasnya lebih lebih besar, lebih tinggi, atau lebih luas merupakan esensi komunikasi ke atas (Pace \& Faules, 2000).

\section{Ketepatan Komunikasi (The Fidelity of Communication)}

David K. Berlo (1960) menjelaskan bahwa ketepatan pada komunikasi terkait erat dengan peranan sebagai source-encoder dan receiver-decoder. Dalam hal ini, seorang komunikator berharap bahwa tindak komunikasinya akan memiliki ketepatan yang tinggi; dengan ketepatan, kita mengartikan bahwa ia akan mendapatkan apa yang diinginkannya. A highfidelity encoder diartikan sebagai seorang yang mengekspresikan arti dari sumber pengirim pesan dengan tepat. Sementara a high-fidelity decoder diartikan sebagai seorang yang mengartikan pesan untuk si penerima dengan akurasi yang sempurna.

1. Source-Encoder dan Receiver-Decoder

Berlo menjelaskan terdapat empat faktor pada sumber (source-encoder) dan pengirim (receiver-decoder) yang bisa meningkatkan ketepatan komunikasi, yaitu keterampilan berkomunikasi, sikap, tingkat pengetahuan, posisi dalam sebuah sistem sosial budaya. 
2. Message

Ada tiga faktor yang yang patut diperhatikan dalam pesan, yaitu kode pesan, isi pesan, dan perlakuan pesan.

3. Channel

Isi, kode dan perlakuan dari pesan berhubungan dengan pilihan kita terhdap saluransaluran. Di waktu yang sama, pengetahuan dari penerima berhubungan dengan pilihan dari saluran-saluran. Ada berbagai hal yang menentukan pemilihan media. Pemilihan dibatasi oleh: (a) apa yang tersedia; (b) berapa banyak uang yang harus dikeluarkan; dan (c) apa yang menjadi pilihan sumber. Hal lain yang menjadi penentu adalah: (a) saluran mana yang banyak diterima oleh banyak orang (dengan biaya yang rendah); (b) saluransaluran mana yang mempunyai pengaruh besar; (c) saluran-saluran mana yang mudah diadaptasikan dengan tujuan-tujuan yang dimiliki pengirim/sumber; dan (d) saluransaluran mana yang mudah diadaptasikan dengan isi dari pesan.

\section{Unsur Pendukung Proses Komunikasi Organisasi}

Dalam melakukan tiap fungsi di dalam sebuah organisasi, terdapat beberapa faktor pendukung yang turut memengaruhi proses komunikasi, antara lain gaya kepemimpinan dan gaya komunikasi.

1. Gaya Kepemimpinan

Pace dan Faules (2000) mendefinisikan gaya kepemimpinan sebagai: cara bekerja sama dengan orang lain yang dilakukan secara konsisten. Melalui ucapan (bahasa) dan tindakan, seseorang membantu orang-orang lainnya untuk mendapatkan hasil yang diinginkan. Cara seseorang berbicara pada orang lain dan caranya bersikap di depan orang lain merupakan suatu gaya kerja.

Sementara itu, Likert (dalam Pace dan Faules, 2000) mengemukakan empat gaya atau sistem manajerial berdasarkan kepada analisis atas delapan variabel manajerial (kepemimpinan, motivasi, komunikasi, interaksi, pengambilan keputusan, penentuan tujuan, pengendalian dan kinerja).

a. Penguasa Mutlak (Exploitive-Authoritative)

Gaya ini berdasarkan pada sumsi Teori X McGregor. Manajer/pemimpin memberi bimbingan sepenuhnya dan pengawasan ketat terhadap pegawai dengan anggapan bahwa cara terbaik untuk memotivasi pegawai adalah dengan memberi rasa takut, 
ancaman, dan hukuman. Interaksi atasan-bawahan amat sedikit; semua keputusan berasal dari atas dan komunikasi ke bawah semata-mata berisi instruksi/perintah.

b. Penguasa Semi-Mutlak (Benevolent-Authoritative)

Gaya ini pada dasarnya bersifat otoritarian, namun mendorong komunikasi ke atas untuk ikut berpendapat atau mengemukakan keluhan bawahan; namun interaksi di antara tingkatan dalam organisasi dilakukan melalui jalur resmi, komunikasi yang terjadi jarang bersifat bebas dan terus terang.

c. Penasihat (Consultative)

Gaya ini melibatkan interaksi yang cukup sering di tingkat pribadi sampai tingkat moderat, antara atasan dan bawahan pada organisasi. Informasi bisa berjalan baik ke atas-ke bawah, tetapi dengan sedikit penekanan pada gagasan yang berasal dari atas. Manajer menaruh kepercayaan besar, meskipun tidak mutlak, dan keyakinan kepada pegawai.

d. Pengajak-Serta (Participative)

Gaya ini sportif, dengan tujuan supaya organisasi berjalan baik melalui partisipasi nyata pegawai. Informasi berjalan ke segala arah, serta pengendalian dijalankan di setiap tingkatan. Orang berkomunikasi dengan bebas, terbuka, dan berterus terang, hampir tanpa rasa takut terhadap hukuman.

\section{Gaya Komunikasi}

Tindak komunikasi seseorang dapat disampaikan dengan berbagai cara. Salah satu cara yang dipakai seseorang untuk berinteraksi dengan orang lain yang membuat pelaku komunikasi tersebut nyaman, bisa diartikan bahwa orang tersebut mempunyai suatu gaya komunikasi tersendiri. Sendjaja (1999) mengartikan gaya komunikasi sebagai seperangkat perilaku antarpribadi yang terspesialisasi yang digunakan dalam suatu situasi tertentu. Lebih lanjut, Sendjaja juga menyebutkan enam gaya komunikasi sebagaimana berikut.

a. The Controlling Style

Gaya komunikasi ini bersifat mengendalikan, yang ditandai adanya kehendak atau maksud untuk membatasi, memaksa/mengatur perilaku, pikiran serta tanggapan orang lain. Orang-orang yang menggunakan gaya komunikasi ini dikenal sebagai komunikator satu arah atau one way communicators. 
b. The Equilitarian Style

Gaya komunikasi ini mempunyai aspek penting yaitu adanya landasan kesamaan. Ditandai dengan berlakunya arus penyebaran pesan-pesan verbal secara lisan atau tertulis yang bersifat dua arah (two way traffic communication).

c. The Structuring Style

Gaya berstruktur memanfaatkan pesan-pesan verbal secara tertulis atau lisan guna memantapkan perintah yang harus dilaksanakan, penjadwalan tugas dan pekerjaan serta struktur organisasi. Pengirim pesan (sender) lebih memberi perhatian kepada keinginan untuk mempengaruhi orang lain dengan jalan berbagi informasi tentang tujuan organisasi, jadwal kerja, aturan dan prosedur yang berlaku dalam organisasi tersebut.

d. The Dynamic Style

Gaya ini memiliki kecenderungan agresif sebab pengirim pesan memahami bahwa lingkungan pekerjaannya berorientasi tindakan (action-oriented). Gaya ini sering dipakai oleh juru kampanye dan supervisor yang membawahi wiraniaga (salesmen atau saleswomen)

e. The Relinquishing Style

Gaya ini lebih mencerminkan kesediaan untuk menerima saran, pendapat, ataupun gagasan orang lain, dibandingkan keinginan memberi perintah meskipun pengirim pesan (sender) mempunyai hak memberi perintah dan mengontrol orang lain.

f. The Withdrawal Style

Gaya ini menyebabkan melemahnya tindak komunikasi. Artinya tak ada keinginan dari orang-orang yang memakai gaya ini untuk berkomunikasi dengan orang lain, lantaran ada beberapa persoalan atau kesulitan antarpribadi yang dihadapi orangorang tersebut.

\section{METODE PENELITIAN}

Penelitian ini dilaksanakan di Gedung Garuda Sentra Operasi (GSO) serta Gedung Manajemen Garuda (GMF) PT. Garuda Indonesia, Bandara Soekarno-Hatta, Cengkareng. Penelitian ini menggunakan pendekatan kualitatif dan pendekatan fenomenologi, dengan model paradigma naturalistik (naturalistic inquiry). Karena penelitian ini termasuk penelitian deskriptif kualitatif maka penelitian ini tidak memakai sampel penelitian, tetapi menggunakan informan penelitian, yaitu individu yang memberikan informasi terkait situasi dan kondisi 
latar belakang penelitian ini. Adapun teknik pengumpulan data yang digunakan adalah observasi partisipan, wawancara mendalam, dan studi dokumentasi.

Teknik analisis data yang digunakan dalam penelitian ini adalah analisis induktif, yaitu dengan mendalami secara rinci dan spesifik atas data-data yang ditemukan, kategori, dimensi, dan antarhubungan mulai dari eksplorasi lewat pertanyaan terbuka, observasi, dan tidak untuk menguji hipotesis. Untuk menguji keabsahan data, peneliti menggunakan triangulasi sumber data, yaitu cara untuk membandingkan atau mengecek ulang derejat kepercayaan sebuah informasi yang didapatkan dari berbagai sumber berbeda (Kriyantono, 2007).

\section{HASIL DAN PEMBAHASAN \\ Source-Encoder}

Dalam hal melakukan rutinitas pekerjaan dan melaksanakan perannya, manajemen banyak melakukan tindak komunikasi dan interaksi dengan Cabin Services (OC) dan juga unit-unit lainnya baik yang terkait secara langsung maupun tidak. Sementara itu, dalam mata rantai manajemen, kedudukan Vice President Cabin Services (VPOC) berkaitan dengan aspek strategis bagi jangka waktu yang pendek, menengah, panjang dan hal itu akan sejalan dengan tujuan perusahaan. Secara garis besar peran dan fungsi VPOC adalah memastikan ketersediaan Awak Kabin yang sesuai dengan kriteria yang ditetapkan perusahaan, terutama dari aspek Safety (IOSA Requirement) dan Service (Skytrax) untuk mendukung operasional utama penerbangan. Program kerja yang telah ditetapkan dengan level top manajemen akan berhasil jika setiap pemimpin pada level tengah memberi tugas dan tanggung jawab yang jelas serta menginformasikan hal-hal yang telah disepakati oleh pihak manajemen. Jadi, komunikasi dalam bentuk koordinasi dan interaksi positif sangat dibutuhkan dalam menentukan keberhasilan tim atau unit yang dipimpinnya.

Dalam proses komunikasi organisasi, baik VPOC maupun Direktur Operasi (DO), menerapkan menerapkan sistem komunikasi keterbukaan. Dengan keterbukaan, keduanya bisa melihat langsung, mendengar langsung serta berbicara langsung dengan awak kabin. Bagi manajemen, sistem keterbukaan dirasakan sangat efektif, karena awak kabin merasa diperhatikan, dengan cara pimpinan mereka bersedia melihat, bertemu, dan juga berbicara langsung. Artinya, manajemen secara tak langsung telah mempraktikkan human relations sebagai landasan dalam berkomunikasi. Human relations pun dirasakan sangat membantu manajemen dalam merangkul awak kabin dalam rangka mencapai tujuan perusahaan atau program-program yang dicanangkan. 
Selain itu, pelaksanaan komunikasi tatap muka yang dilakukan merupakan suatu bentuk peruntuhan barrier dan meminimalisir celah komunikasi yang mungkin terbentuk (Conrad, 2014, Luthra \& Dahiya, 2015; Yusanto, 2018). Peneriapan sistem komunikasi yang terbuka juga didukung oleh keterampilan komunikasi yang dimiliki VPOC serta DO, antara lain membaca, menulis, dan mendengarkan Hal lain yang juga mendukung adalah sikap positif seperti menghargai diri sendiri dan juga orang lain. Dengan dipraktikkannya sikap menghargai, penerima pesan (receiver-decoder) akan merasa berdiri sama tinggi dan duduk sama rendah, sehingga informasi yang disampaikan dapat mengalir tanpa hambatan yang berarti.

Sementara itu, knowledge level yang dimiliki pihak manajemen antara lain terlihat dari keinginan manajemen memanfaatkan perkembangan teknologi dalam berkomunikasi, sehingga bisa mengatasi kendala ruang dan waktu. Hal ini juga merupakan indikator dari konsistensi penerapan keterbukaan dalam berkomunikasi. Dalam hal kedudukan di tengah sistem sosial-budaya, baik VPOC maupun DO selaku manajemen mampu mempraktikkan model komunikasi sesuai dengan keadaan atau persoalan yang sedang dihadapi, misalnya lebih mengutamakan penggunaan komunikasi tatap muka ketika berhadapan dengan awak kabin ketimbang menggunakan media atau saluran formal lainnya (memo, surat, dan lainlain).

\section{Message}

Pesan yang disampaikan manajemen pada awak kabin adalah gabungan dari kode-kode yang dipilih untuk membentuk sebuah struktur kalimat tertentu. Penyusunan pesan sebagai bentuk kode pesan, tidak dapat terlepas dari pemilihan kata sebagai dasar elemen atau inti dari struktur yang akan dibuat sehingga dapat menghindari kesalahan pemaknaan atas pesan yang disampaikan tersebut.

Kegiatan penyusunan kalimat sederhana dan kompleks dalam korespondensi oleh manajemen akan menggunakan bahasa Indonesia yang formal. Apabila bersifat persuasif, akan digunakan kalimat persuasif, begitu pula apabila pesan bersifat informasi/narasi atau argumentasi. Dalam komunikasi internal yang khusus membicarakan aturan, pesan yang hendak disampaikan bersifat satu arah, sementara itu dalam penerbangan, karena cenderung banyak berbicara tentang kebijakan situasional serta menyangkut interaksi antarmanusia, pesan bersifat dua arah.

\section{Channel}

Manajemen memiliki wewenang dalam hal menentukan dan memutuskan channel mana yang akan dipakai untuk menyampaikan pesan kepada awak kabin, khususnya yang 
menyangkut teknis pekerjaan. Sementara saluran komunikasi yang digunakan ialah media cetak, media elektronik (SMS) dan media sosial seperti Whatsapp, Facebook, Instagram, dan Twitter dalam bentuk kelompok (group) sesuai jenjang/kelompok/kepangkatan pada awak kabin: junior flight attendant (JRFA), senior flight attendant (SRFA), flight service manager (FSM). Untuk informasi yang berasal dari korporasi, sebagian besar media telah dipilih dan didistribusikan oleh unit internal komunikasi perusahaan.

Pemilihan channel untuk pengiriman pesan pada awak kabin akan memperhatikan bahwa penerima (receiver) bisa menyandi balik (decode) lewat penginderaannya: melihat, mendengar, menyentuh, atau bahkan merasakannya dan membauinya, sehingga terbentuk efek positif berupa feedback. Selain itu, pemilihan channel juga ditentukan oleh ukuran dan komposisi audiens, sebab audiens dalam jumlah besar tentu saja akan memperlihatkan perilaku yang berbeda dengan audiens yang berjumlah sedikit, sehingga untuk menghadapinya diperlukan teknik komunikasi yang berbeda pula. Dari berbagai saluran tersebut, manajemen tetap "merasa" jika komunikasi yang dilakukan secara tatap muka jauh lebih efektif dibandingan dengan berbagai media yang digunakan.

\section{Receiver-Decoder}

Dalam kedudukannya yang memegang posisi puncak dalam manajemen, Direktur Operasi (DO) akan bertindak sebagai receiver-decoder pada saat ia memberikan feedback kepada lawan bicara yang ditujunya, begitu pula dengan VPOC. Lewat feedback tersebut, baik secara langsung maupun tak langsung, bisa menjadi landasan untuk mengevaluasi efektivitas komunikasi yang berlangsung dalam perusahaan. Selain itu, evaluasi juga sangat diperlukan bagi pihak manajemen untuk mencari solusi, terutama untuk perbaikan komunikasi pada masa mendatang serta demi mencapai tujuan perusahaan (DeMaria, 2016; Hogard \& Ellis, 2006).

\section{Hambatan Komunikasi (Noise)}

Noise merupakan berbagai faktor yang mengganggu proses komunikasi. Perluasan arti noise termasuk pada faktor-faktor yang bisa mengurangi efektivitas pada komunikasi (Berlo, 1960: 40). Lebih jauh, Berlo menyebutkan bahwa noise dan fidelity bagaikan dua sisi mata uang. Jadi, menghilangkan noise bisa meningkat fidelity, dan begitu sebaliknya (Kelly, 2000; Sethi \& Seth, 2009; Stephens, Barrett \& Mahometa, 2013).

Salah satu gangguan dalam proses komunikasi yang terjadi antara manajemen dan awak kabin adalah belum tumbuhnya keinginan dari awak kabin untuk menjadikan proses komunikasi sebagai kebutuhan. Artinya, awak kabin masih enggan berkomunikasi dengan manajemen 
sekalipun keterbukaan sudah diperlihatkan manajemen. Gangguan atau noise lainnya adalah tingginya mobilitas awak kabin yang juga berdampak pada belum optimal dan maksimalnya proses komunikasi yang berlangsung.

\section{PENUTUP}

\section{Kesimpulan}

Dalam proses komunikasi organisasi yang berlangsung di antara pihak manajemen dengan awak kabin, manajemen sudah berupaya menerapkan sistem keterbukaan dan juga lebih mementingkan komunikasi tatap muka daripada komunikasi satu arah dan sekaligus mempraktikkan human relations sebagai landasannya dalam berkomunikasi. Penyusunan pesan juga dilakukan dengan penyesuaian; jika bersifat persuasif, akan digunakan kalimat persuasif, begitu pula apabila pesan bersifat informasi (narasi) atau argumentasi. Sebagai bagian dari keterbukaan komunikasi, pemilihan channel untuk pengiriman pesan terhadap awak kabin akan memperhatikan jika penerima (receiver) dapat menyandi balik (decode) lewat penginderaannya: melihat, mendengar, menyentuh, atau bahkan merasakannya dan membauinya, sehingga terbentuk feedback positif. Akan tetapi, awak kabin masih enggan berkomunikasi dengan manajemen meskipun keterbukaan komunikasi telah dilaksanakan oleh manajemen. Adapun faktor lainnya adalah tingginya mobilitas awak kabin sehingga komunikasi belum berjalan efektif.

\section{Saran}

1. Untuk mengatasi hambatan (noise) mobilitas awak kabin yang tinggi bisa dibuat suatu program komunikasi tatap muka dengan pihak manajemen yang lebih variatif, kreatif, dan inovatif:

a. Membuat kelompok berdasarkan tempat tinggal, hobi atau olahraga.

b. Memilih tempat pertemuan yang berbeda, seperti di hotel atau tempat-tempat lain.

c. Mengadakan acara forum bulanan yang bertempat di Area GSOm.

2. Guna membangun budaya information seeking di kalangan awak kabin, antara lainnya dapat dilakukan dengan cara berikut ini.

a. Membuat suatu budaya high demand of information di lingkungan Cabin Services. Dibutuhkan "kesediaan" pihak manajemen untuk memenuhi diri dengan informasi terkini dan selalu siap memberikan informasi kepada awak kabin melalui berbagai sarana komunikasi dan teknologi yang ada tanpa melihat batasan ruang dan waktu. 
b. Membuat seminar (in house training) khusus untuk awak kabin supaya menambah pengetahuan keawakkabinan, bekerja sama dengan unit terkait. Hal ini diharapkan juga bisa menimbulkan motivasi bagi awak kabin.

c. Membuat tampilan media yang telah menjadi lebih menarik lagi, seperti pemilihan kata/istilah, atau memuat profil awak kabin secara rutin melalui koordinasi dengan unit terkait.

\section{REFERENSI}

Afriyadi, Ferry. (2015). “Efektivitas Komunikasi Interpersonal antara Atasan dan Bawahan Karyawan PT. Borneo Enterprsindo Samarinda”. eJournal Ilmu Komunikasi, 3(1): 362-376.

Berlo, David K. (1990). The Process of Communication: An Introduction to Theory and Practise. Holt, Rinehart and Winston.

Bungin, Burhan. (2007). Penelitian Kualitatif: Komunikasi, Ekonomi, Kebijakan Publik, dan Ilmu Sosial Lainnya. Jakarta: Kencana Prenada.

Conrad, David. (2014). "Workplace Communication Problems: Inquiries by Employees and Applicable Solutions". Journal of Business Studies Quarterly, 5(4): 105-116.

DeMaria, Kristen. (2016). "Evaluating the Internal Communications of the Triangle's 'Best Places to Work'". Elon Journal of Undergraduate Research in Communications, 7(1): 7078.

Harivarman, Dwi. (2017). “Hambatan Komunikasi Internal di Organisasi Pemerintahan”. Jurnal ASPIKOM, 3(3): 508-519.

Hogard, Elaine \& Roger Ellis. (2006). "Evaluation and Communication: Using a Communication Audit to Evaluate Organizational Communication". Evaluation Review, 30(2): 171187.

Johanna, Pricillia. (2013). "Hambatan Downward Communication antara Pimpinan dan Karyawan PT Makmur Jaya". Jurnal E-Komunikasi, 1(2): 25-37.

Kelly, Dawn. (2000). “Using Vision to Improve Organisational Communication”. Leadership \& Organization Development Journal, 21(2): 92-101.

Klimova, Blanka Frydrychova \& Ilona Semradova. (2012). "Barriers to Communication". Procedia (Social and Behavioral Sciences), Volume 31, 207-211.

Kriyantono, Rachmat. (2007). Teknik Praktis Riset Komunikasi. Jakarta: Prenada Media.

Kusni Ingsih, Kusni. (2011). "Efektivitas Komunikasi dalam Organisasi”. Media Ekonomi \& Teknologi Informasi, 17(2): 157-178.

Kuswarno, Engkus. (2001). “Efektivitas Komunikasi Organisasi”. MediaTor, 2(1): 55-51. 
Londa, Baraney Nicolas, Johny Senduk \& Anthonius Boham. (2014). “Efektivitas Komunikasi Antar Pribadi dalam Meningkatkan Kesuksesan Sprakle Organizer". Jurnal Acta Diurna, 3(1): 1-8.

Lunenburg, Fred C. (2010). "Communication: The Process, Barriers, And Improving Effectiveness". SCHOOLING, 1(1): 1-11.

Luthra, Anchal \& Richa Dahiya. (2015). "Effective Leadership is all About Communicating Effectively: Connecting Leadership and Communication". International Journal of Management \& Business Studies (IJMBS), 5(3): 43-48.

Nurhayani. (2011). "Peran Komunikasi Interpersonal dalam Upaya Meningkatkan Kualitas Pelayanan Perpustakaan". Jurnal lqra', 5(1): 12-22.

Pace, R. Wayne, dan Don F. Faules. (2000). Komunikasi Organisasi: Strategi Meningkatkan Kinerja Perusahaan. Bandung: PT. Remaja Rosdakarya.

Pawito. (2008). Penelitian Komunikasi Kualitatif. Yogyakarta: LKiS.

Prabawanti, Benedicta Evienia. (2008). "Peran Komunikasi sebagai Pendukung Perubahan Organisasi". Bina Ekonomi, 12(1): 78-86.

Ruben, Brent D. (1993). Communication and Human Behaviour. New Jersey: Prentice.

Ruslan, Rosady. (2004). Metode Penelitian Public Relations dan Komunikasi. Jakarta: PT. RajaGrafindo Persada.

Sendjaja, Sasa Djuarsa. (1999). Pengantar Komunikasi. Jakarta: Universitas Terbuka.

Sethi, Deepa \& Manisha Seth. (2009). "Interpersonal Communication: Lifeblood of an Organization". The IUP Journal of Soft Skills, 3 (3-4): 32-40.

Sidauruk, Paraden Lucas. (2013). "Analisis Hambatan Komunikasi Organisasi Vertikal PT Pos Indonesia (Persero) (Kasus pada Kantor Pos Medan)". Jurnal Penelitian Pos dan Informatika, 3(2): 133-164.

Stephens, Keri K., Ashley K. Barrett \& Michael J. Mahometa. (2013). “Organizational Communication in Emergencies: Using Multiple Channels and Sources to Combat Noise and Capture Attention". Human Communication Research, 38(2): 230-251.

Suherman, Maman. (2010). "Konstelasi Kemampuan "Listening” dalam Komunikasi Tatap Muka". MEDIATOR, 1(1): 93-103.

Tubbs, Stewart L. dan Sylvia Moss. (1996). Human Communication: Konteks-Konteks Komunikasi (Buku Kedua). Bandung: PT. Remaja Rosdakarya.

Wijaya, Ida Suryani. (2013). "Komunikasi Interpersonal dan Iklim Komunikasi dalam Organisasi". Jurnal Dakwah Tabligh, 14(1): 115-126.

Yusanto, Freddy. (2018). “Analisis Proses Komunikasi Interpersonal Mahasiswa Kelas Produksi Film Dokumenter saat Brainstorming Ide dan Pembuatan Karya Film". Nyimak Journal of Communication, 2(1): 71-79. 
